\title{
SUPPRESSION OF SERUM-INDUCED c-jun EXPRESSION BY ACTIVATED Ki-ras IN HUMAN COLON CANCER CELLS
}

\author{
Masanori Furuse, Senji Shirasawa, Koji OKumura, \\ Mariko OHMORI, and Takehiko SASAZUKI* \\ Department of Genetics, Medical Institute of Bioregulation, Kyushu University, \\ 3-1-1 Maidashi, Higashi-ku, Fukuoka 812-82, Japan
}

Summary Through gene-targeting, we have established human colon cancer cell lines, HK2-6 and HKe-3, with and without activated Ki-ras, respectively, derived from a human colon cancer cell line HCT116, and we have reported that activated $\mathrm{Ki}$-ras is involved in the deregulation of c-myc expression. To further examine the relation between $\mathrm{Ki}$-rasmediated signals and other immediate early genes, $c-j u n$ was analyzed on these cells stimulated by serum. Rapid and strong induction of c-jun was observed in HKe-3, but not in HCT116 or HK2-6. To elucidate the regulatory mechanisms of c-jun expression by $\mathrm{Ki}-$ ras, protein kinase $\mathrm{C}$ (PKC) and c-Raf were examined at serum-starved and serum-stimulated conditions. Phosphorylations of c-Raf were same among these cells, however, the cytosolic PKC activity in HKe-3 was two times higher than that in HCT116 on serum-starved and serum-stimulated conditions. These results suggested that serum responsiveness of $c-j u n$ may be suppressed by activated $\mathrm{Ki}$-ras through PKC rather than $\mathrm{c}-\mathrm{Raf}$ pathway in colon cancer cells.

Key Words serum responsiveness, activated $\mathrm{Ki}$-ras, colon cancer, c-jun, protein kinase C, c-Raf

\section{INTRODUCTION}

We previously demonstrated that activated $\mathrm{Ki}$-ras is involved in the deregulation of c-myc in human colon cancer cell lines using the gene-targeting system (Shirasawa et al., 1993). These results raised the possibility that activated Ki-ras will be involved in the deregulation of other immediate early genes, such as c-jun, which is involved in growth, differentiation, and apoptosis (Kitabayashi et al., 1991; Verheij et al., 1996).

c-Jun belongs to AP-1 family, whose expression is rapidly stimulated by

Received July 11, 1997; Accepted July 23, 1997.

* To whom correspondence should be addressed. 
serum, forming homodimers and/or heterodimers with other AP-1 families (Angel et al., 1988). c-Jun was activated by phosphorylation on serine resides 63 and 73 through Ha-ras-mediated signals in fibroblasts (Smeal et al., 1992). To elucidate whether activated $\mathrm{Ki}$-ras is involved in the regulation of c-jun, expressions of c-jun mRNA and c-Jun were investigated on the colon cancer cells disrupted at activated Ki-ras (HKe-3) and its parental cells (HCT116). Activities of PKC and phosphorylation of c-Raf, which are downstream targets of Ras, were also examined on these cells.

\section{MATERIALS AND METHODS}

Cell culture. Colon cancer cell line HCT116 [American Tissue Culture Collection (ATCC) CCL 247] was obtained from ATCC. HCT 116 has a mutation of Ki-ras at codon 13. HK2-6 and HKe-3 are clones derived from HCT116, with and without activated $\mathrm{Ki}$-ras, respectively, through gene-targeting (Shirasawa et al., 1993). These cell lines were grown in Dulbecco's modified eagle's medium (DMEM) supplemented with $10 \%$ fetal calf serum (FCS) in a humidified atmosphere of $10 \% \mathrm{CO}_{2}$.

$R N A$ preparation. Cultured cells $\left(5 \times 10^{6}\right)$ from each cell line were lysed with $5 \mathrm{ml}$ of the denaturing solution containing $1 \%$ sodium dodecyl sulfate (SDS), 10 $\mathrm{mM}$ sodium acetate ( $\mathrm{pH} 4.5)$. The lysate was transferred to a $15 \mathrm{ml}$ polypropylene tube, and $5 \mathrm{ml}$ of water saturated phenol was added. The solution was shaken vigorously at $70^{\circ} \mathrm{C}$ for $7 \mathrm{~min}$, and then shaken in dry-iced alcohol for $3 \mathrm{~min}$, followed by centrifugation at $3,000 \mathrm{rpm}$ for $20 \mathrm{~min}$. The upper aqueous phase was transferred to a fresh tube, subsequently extracted by $25 / 24 / 1$ phenol/chloroform/ isoamyl alcohol once, then by $24 / 1$ chloroform/isoamyl alcohol. The aqueous phase was precipitated with 2.5 volumes of ethanol and $1 / 10$ volumes of sodium acetate ( $\mathrm{pH}$ 5.2). The precipitant RNAs were centrifuged at $15,000 \mathrm{rpm}$ at $4^{\circ} \mathrm{C}$, then the pellet was suspended in diethyl pyrocarbonate treated water.

Northern blot analysis. Fifteen micrograms of total RNA isolated from each cell line were electrophoresed in $1 \%$ agarose gel containing $20 \mathrm{mM}$ MOPS, $5 \mathrm{mM}$ sodium acetate ( $\mathrm{pH} 4.5), 1 \mathrm{mM}$ EDTA, and $2.2 \mathrm{M}$ formaldehyde at $140 \mathrm{~V}$ for $3 \mathrm{hr}$ followed by transfer to nylon membrane (Hybond $\mathrm{N}+$, Amersham). The filters were hybridized with ${ }^{32} \mathrm{P}-$ labeled DNA probes in solution containing $50 \%$ of deionized formamide, $5 \times \mathrm{SSPE}, 10 \times$ Denhardts $(0.1 \%$ polyvinylpyrrolidone, $0.1 \%$ Ficoll, and $0.1 \%$ bovine serum albumin), $1 \% \mathrm{SDS}$, and $100 \mu \mathrm{g} / \mathrm{ml}$ sonicated salmon sperm DNA at $42^{\circ} \mathrm{C}$ overnight. The filters were washed in solution containing $2 \times \mathrm{SSPE} / 0.1 \% \mathrm{SDS}$ at room temperature for $10 \mathrm{~min}$, and then washed with $2 \times \mathrm{SSPE} / 0.1 \%$ SDS at $55^{\circ} \mathrm{C}$. The washed filters were exposed to Bio-ImageAnalyzer (BAS2000, FUJIX, Kanagawa, Japan) for the radioactivity of each band, and then the filters were exposed to Kodak XAR-5 film for 2-8 days. c-jun probe was generated by PCR using primer set, $5^{\prime}$-GCAGAGTCCCGGAGCGAACT-3' 
and 5'-CACTGTCTGAGGCTCCTCCT-3' (Angel et al., 1988; Hattori et al., 1988).

Serum stimulation. Cells $\left(5 \times 10^{6}\right)$ of each line were cultured in DMEM containing $0.1 \% \mathrm{FCS}$ for $40 \mathrm{hr}$ followed by adding serum to the final concentration of $10 \%$. Cells were harvested at each time point; $0 \mathrm{~min}$ (before), $15 \mathrm{~min}, 30 \mathrm{~min}, 60 \mathrm{~min}$, $180 \mathrm{~min}$, amd $360 \mathrm{~min}$. The extracted RNAs were subjected to Northern blot analysis.

Western blot analysis. Proteins were extracted from HCT116 and HKe-3 at serum-starved and serum-stimulated conditions. Fifteen micrograms of total lysates were electrophoresed in $8 \%$ SDS/PAGE at a constant current of $18 \mathrm{~mA}$ for 90 min followed by transfer to PVDF membrane (NCI). Western blotting were performed by ECL system (Amarsham) using anti c-Jun monoclonal antibody (Transduction Laboratories) and anti Raf- 1 polyclonal antibody (Santa Cruz). Phosphorylated status of c-Raf proteins were determined by their mobility difference in SDS/PAGE as reported (Morrison et al., 1988).

Assay for protein kinase $C$. Cultured cells were rinsed with cold PBS and scraped with $0.5 \mathrm{ml}$ of a buffer containing $20 \mathrm{mM}$ Tris $-\mathrm{HCl}$ (pH 7.5), $0.5 \mathrm{mM}$ EDTA, $0.5 \mathrm{mM}$ EGTA, $0.5 \%$ Triton X-100, $25 \mu \mathrm{g} / \mathrm{ml}$ of aprotinin and leupeptin, followed by homogenization in pre-cooled dounce homogenizer. After removing cellular debris by centrifuging for $2 \mathrm{~min}$, the supernatant were partially purified by $\mathrm{DEAE}$ cellulose column. The eluates were used for measuring activity of protein kinase $\mathrm{C}$ according to the manufacturer's protocol (GIBCO BRL). Total protein concentrations were determined by the method of Bradford et al. (1976).

\section{RESULTS}

First, we examined expressions of immediate genes at exponentially growing state in HCT116, HK2-6 and HKe-3. However, no remarkable difference was observed except c-myc expression among these cells (Shirasawa et al., 1993; data not shown).

Next, we analyzed c-jun expression at serum-starved-, serum-stimulated conditions. HCT116, HK2-6, and HKe-3 were stimulated by serum following serum starvation for $40 \mathrm{hr}$. HKe-3 clearly showed c-jun mRNA expression induced by serum at $30 \mathrm{~min}$ and the maximum expression was observed at $60 \mathrm{~min}$ (Fig. 1). Expression of c-jun in $\mathrm{HKe}-3$ was gradually decreased after $60 \mathrm{~min}$, and it came back to the basal level at $360 \mathrm{~min}$. Whereas, in HCT116 and HK2-6 having activated Ki-ras, little serum-induced expression of c-jun were observed (Fig. 1; data not shown). The expression of c-jun in $\mathrm{HKe}-3$ was as 10-15 times as much as that observed in HCT116.

To confirm expression of c-Jun protein, Western blotting was done on HCT116 and $\mathrm{HKe}-3$ at various conditions using anti-c-Jun antibody. At exponentially growing- and serum-starved-conditions, c-Jun expression of HCT116 was lower than that of HKe-3, suggesting that basal level of c-Jun in HCT116 was suppressed on these conditions (Fig. 2; data not shown). Total amount of c-Jun in 
HCT116 was increased at $30 \mathrm{~min}$ after serum stimulation, however, no evidential phosphorylation was observed (Fig. 2). HKe-3 clearly showed c-Jun production at $30 \mathrm{~min}$ and its mobility was shifted due to its phosphorylation (Fig. 2). These results suggested that mRNA- and protein-expression of $c-j u n$ were correlated with each other.

To elucidate the relation between the differential c-Jun expression and activated Ki-ras-mediated signaling pathway, phosphorylation of c-Raf, one of the

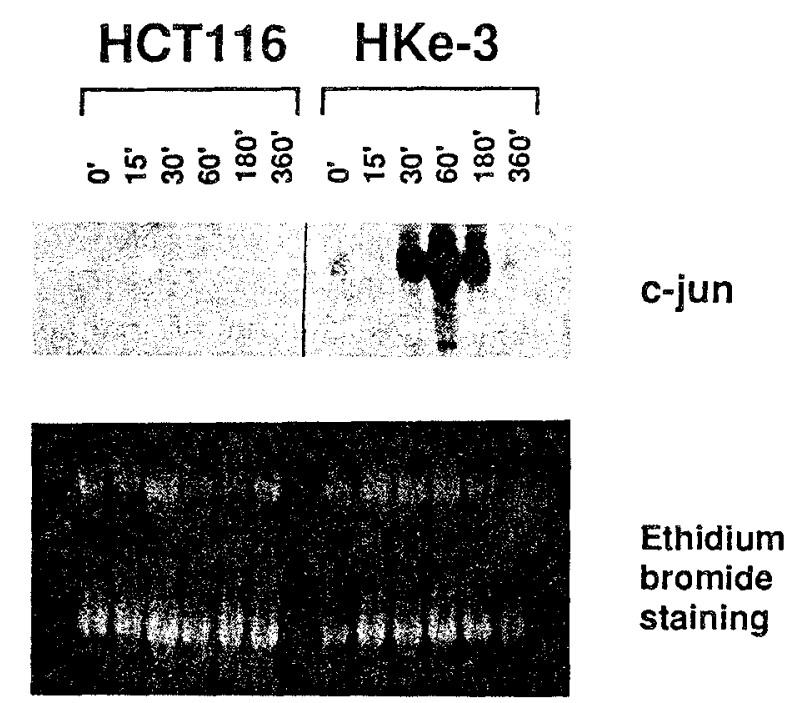

Fig. 1. Time course of c-jun mRNA expression induced by serum in HCT116 and HKe-3. The expression of c-jun and ethidium bromide staining as control were indicated.

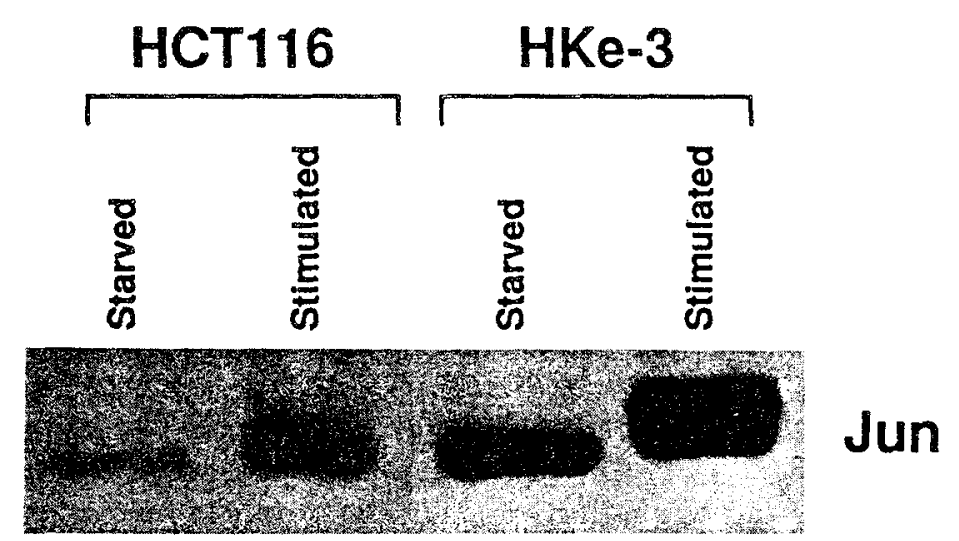

Fig. 2. c-Jun expression and its phosphorylation at serum-starved and serum-stimulated $(30 \mathrm{~min})$ conditions. 
downstream targets of Ras, was examined through a mobility difference between hyper-phosphorylated and hypo-phosphorylated form on SDS-PAGE. Same samples used for c-Jun Western blotting were examined for phosphorylation of c-Raf. Hyperphosphorylated and hypophosphorylated components of c-Raf were indicated by arrows (Fig. 3). On serum stimulation, phosphorylated c-Raf were increased in both HCT116 and HKe-3. No difference of c-Raf was observed among these cells quantitatively and qualitatively at serum-starved- and serum-stimulatedconditions (Fig. 3). These results, together, suggested that $c-R a f$ signaling pathway would not be involved in the differential expression of c-jun mRNA and c-Jun protein in these colon cancer cells.

PKC, which is proposed as another component functioning downstream of Ras, was examined between these cells (Hunter, 1991). When PKC is stimulated by biological active substances such as 12-O-tetradecanoylphorbol-13-acetate (TPA), it is activated and rapidly translocates from cytosol to membrane (Nishizuka, 1992; Chida et al., 1986a). The activities of cytosolic PKC in HCT116 and HKe-3 at serum-starved condition were $125,284 \mathrm{pmol} / \mathrm{min} / \mathrm{mg}$ protein, respectively. The activity in. HCT 116 was almost twofold lower than that in HKe-3 before serum stimulation (Fig. 4). After serum stimulation, PKC activities in both HCT116 and HKe-3 were rapidly decreased about $40 \%$ within $15 \mathrm{~min}$. The decrease of PKC activity in HCT116 was also 2-3-times lower than in HKe-3. The decrease of PKC activity in cytosolic fraction implies translocation of PKC from cytosol to membrane and the decrease in the cytosol fraction was almost equal to the increase

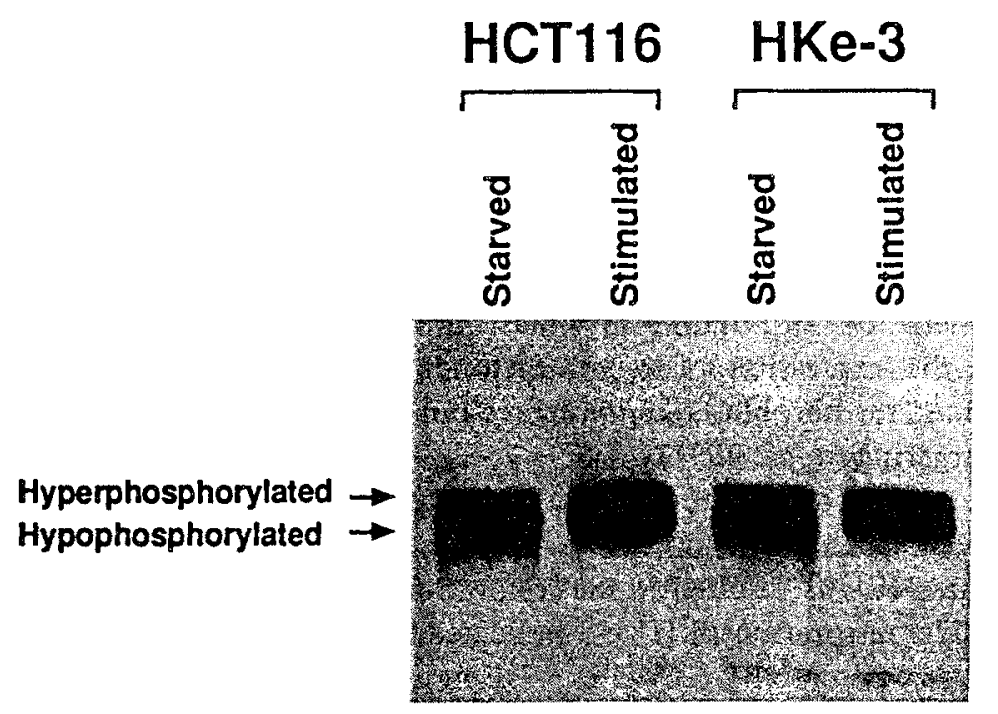

Fig. 3. Western blot analysis of c-Raf protein at serum-starved and serum-stimulated (30 $\mathrm{min})$ conditions. 


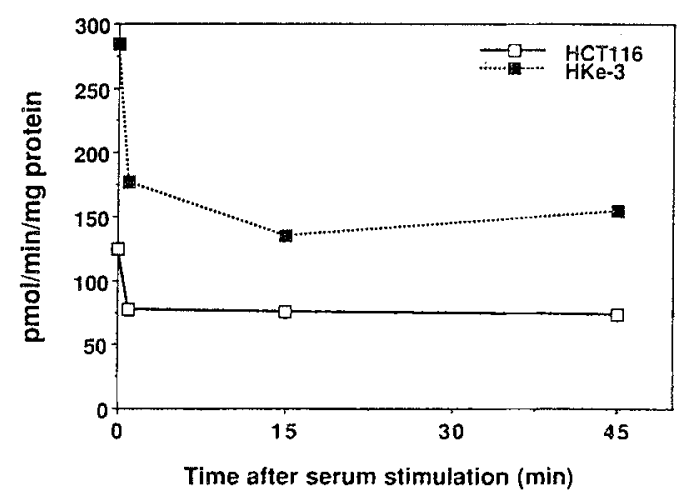

Fig. 4. Time course of cytosolic PKC activity in HCT 116 and $\mathrm{HKe}-3$ at serum-starved and serum-stimulated conditions.

in the membrane fraction, where PKC functions (Chida et al., 1986a,b). The difference of PKC activities between the cells may affect the biological responses to serum stimulation.

\section{DISCUSSION}

The proto-oncogene c-jun shows numerous cellular phenotypes such as oncogenic transformation, differentiation, and the response to toxic agents (Smeal et al., 1991; Kitabayashi et al., 1991; Verheij et al., 1996). The diversity of functions by c-Jun will be due to its combinatorial association with other members of transcriptional factors that exhibited distinct DNA binding specificity (Nakabeppu et al., 1988; Hai and Curren, 1991). The transcriptional response of the c-jun is regulated post-translationally by protein phosphorylations (Angel et al., 1988). Analysis of c-Jun phosphorylation suggests that c-Jun is activated by phosphorylation on serine resides through $\mathrm{Ha}$-ras in fibroblasts (Smeal et al, 1992; Binetruy et al., 1991).

However, the relation between activated $\mathrm{Ki}$-ras and c-jun expression was not fully understood. In NIH3T3 fibroblast, transient expression of activated Ha-ras induced the expression of c-jun (Sistonen et al., 1989). Whereas, in Ha-ras transformed rat fibroblasts, c-jun expression was induced little by serum stimulation (Burgering et al., 1991).

The present report introduces a novel system to comparatively investigate the role of activated $\mathrm{Ki}$-ras in colon cancer cells. This system showed that elimination of activated $\mathrm{Ki}$-ras resulted in the restoration of serum responsiveness of c-jun in HKe-3. The restoration in HKe-3 indicated that HCT116 have serum responsiveness of c-jun potentially. Lower expression of c-Jun was also observed in HCT116 on exponentially growing- and serum-starved-conditions (Fig. 2; data not shown). These observations indicated that in colon cancer cells with activated Ki-ras, the 
expression of c-jun mRNA and c-Jun protein would be suppressed. These phenomenon also indicated that intracellular changes of molecules involved in the regulation of c-jun expression occurred in the colon cnacer cells having activated Ki-ras (Satake et al., 1989; Nishizuka, 1986; Wolfmann and Macara, 1987; Wolfmann et al. 1987).

c-Raf and PKC, candidate molecules downstream of Ras, were also investigated. c-Raf phosphorylation, which is thought to be active form, was not different among those cells (Fig. 3), indicating that activation of c-Raf could not explain the differential expression of c-jun in these cells. While the activity of PKC in HCT116 was almost twofold lower than that in HKe-3 before and after serum stimulation (Fig. 4). After serum-stimulation, cytosolic PKC activities in both HCT 116 and $\mathrm{HKe}-3$ were rapidly decreased about $40 \%$ within 15 min. The extent of decrease in cytosolic PKC activities was also twofold lower in HCT116 than in HKe-3. The decrease of PKC activity in the cytosolic fraction implies the translocation of cytosolic PKC to the membrane and the decrease was almost equal to the increase in the membrane fraction during the first $2 \mathrm{hr}$ after stimulation (Chida et al., 1986a). The membrane fraction of PKC was biologically active and was essential for cellular responses such as cell proliferation and differentiation (Nishizuka, 1992). Therefore, 2-3-fold difference in PKC activities between HCT116 and HKe-3, when the cells were stimulated by serum, may affect the serum responsiveness of c-jun.

To confirm that PKC could mediate signals to c-Jun in these cells, TPA, which was a potent stimulator of PKC, was added to these cells. TPA induced c-Jun expression in HKe-3 like serum stimulation, but not in HCT116 or HK2-6 (data not shown). These observations suggested that PKC would be involved in the responsiveness of c-jun in the colon cancer cells and that the differential expression of c-jun between HCT116 and HKe-3 may be caused through the differential PKC activities.

However, they might just reflect the result of cellular phenotypes because PKC activities were controlled in complex mechanisms (Nishizuka, 1986). Kinase activity of Mitogen Activating Protein Kinases, including ERK, JNK (SAPK), and $\mathrm{p} 38$ should be determined, leading to the elucidation of $\mathrm{Ki}$-ras-mediated signal transductions in colon cancer cells. This system will be useful for understanding the functions of $\mathrm{Ki}-r a s, c-m y c, c-j u n$, and other genes involved in colorectal tumorigenesis.

Acknowledgments This work was supported by Cancer Research Grant-in-Aid from the Ministry of Education, Science, Sports and Culture of Japan. We appreciate Y Hagishima for her secretarial assistance.

\section{REFERENCES}

Angel P, Hattori K, Smeal T, Karin M (1988): The jun proto-oncogene is positively autoregulated 
by its product, Jun/AP-1. Cell 55: $875-885$

Binetruy B, Smeal T, Karin M (1991): Ha-ras augments c-Jun activity and stimulates phosphorylation of its activation domain. Nature 351: 122-127

Bradford MM (1976): A rapid and sensitive method for the quantitation of microgram quantities of protein utilizing the principle of protein dye binding. Ann Biochem 72: 248-254

Burgering BMT, Medema RH, Maasen JA, Van Der Weterin ML, Van Der Eb AJ, McCormick F, Bos JL (1991): Insulin stimulation of gene expression mediated by p21ras activation. EMBO J 10: 1103-1109

Chida K, Hashiba H, Sasaki K, Kuroki T (1986a): Activation of protein kinase C and specific phosphorylation of a $\mathrm{M}_{\mathrm{r}} 90,000$ membrane protein of promotable BALB/3T3 and $\mathrm{C} 3 \mathrm{H} /$ $10 \mathrm{~T}_{1 / 2}$ cells by tumor promoters. Cancer Res 46: 1055-1062

Chida K, Kato N, Kuroki T (1986b): Down regulation of phorbol diester receptors by proteolytic degradation of protein kinase $\mathrm{C}$ in a cultured cell line of fetal rat skin keratinocytes. $\mathrm{J}$ Biol Chem 261: 13013-13018

Hai T, Curren T (1991): Cross-family dimerization of transcription factors Fos/Jun and ATF/ CREB alters DNA binding specificity. Proc Natl Acad Sci USA 88: $3720-3724$

Hattori K, Angel P, Le Beau MM, Karin M (1988): Structure and chromosomal localization of the function intronless human JUN protooncogene. Proc Natl Acad Sci USA 85: $9148-9152$

Hunter T (1991): Cooperation between oncogenes. Cell 64: 249-270

Kitabayashi I, Kawakami Z, Cjiu R, Ozawa K, Matsuoka T, Toyoshima S, Umesono K, Evans RM, Gachelin G, Yokoyama K (1991): Transcriptional regulation of the c-jun gene by retinoic acid and E1A during differentiation of F9 cells. EMBO J 11: 167-175

Morrison DK, Kaplan DR, Rapp U, Roberts TM (1988): Signal transduction from membrane to cytoplasm: growth factors and membrane-bound oncogene products increase Raf-1 phosphorylation and associated protein kinase activity. Proc Natl Acad Sci USA 85: 8855-8859

Nakabeppu Y, Ryder K, Nathans D (1988): DNA binding activities of three murine Jun proteins: Stimulation by Fos. Cell $\mathbf{5 5} 907-915$

Nishizuka Y (1986): Studies and perspectives of protein kinase C. Science 233: 305-312

Nishizuka Y (1992): Intracellular signaling by hydrolysis of phospholipids and activation of protein kinase C. Science 258: $607-614$

Satake M, Ibaraki T, Yamaguchi Y, Ito Y (1989): Loss of responsiveness of and AP-1-related factor, PEBP1, to 12-O-tetradecanoylphorbol-13-acetate after transformation of NIH3T3 cells by the Ha-ras oncogene. Mol Cell Biol 63: 3669-3677

Shirasawa S, Furuse M, Yokoyama N, Sasazuki T (1993): Altered growth of human colon cancer cell lines disrupted at activated Ki-ras. Science 260: $85-88$

Sistonen L, Hölttä E, Mäkelä TP, Kesi-Oja J, Alitalo K (1989): The celllular response to induction of the p $21^{\mathrm{c}-\mathrm{Ha}-\mathrm{ras}}$ oncoprotein includes stimulation of jun gene expression. EMBO $\mathrm{J}$ 8: $815-822$

Smeal T, Binetruy B, Mercola DA, Birrer M, Karin M (1991): Oncogenic and transcriptional cooperation with Ha-Ras requires phosphorylation of c-Jun on serines 63 and 73 . Nature 354, 494-496

Smeal T, Binetruy B, Mercola D, Gover-Bardwick A, Heidecker G, Rapp UR, Karin M (1992): Oncoprotein-mediated signaling cascade stimulates c-Jun activity by phosphorylation of serine 63 and 73. Mol Cell Biol 12: 3507-3513

Verheij M, Bose R, Lin XH, Yao B, Jarvis WD, Grant S, Birrer MJ, Szabo E, Zon LI, Kyriakis JM, Haimovitz-Friedman A, Fuks Z, Kolesnick RN (1996): Requirement for ceramideinitiated SAPK/JNK signalling in stress-induced apoptosis. Nature 380: 75-79

Wolfmann A, Macara IG (1987): Elevated levels of diacylglycerol and decreased phorbol ester sensitivity in ras-transformed fibroblasts. Nature (London) 325: 359-361

Wolfmann A, Wingrove TG, Blackshear PJ, Macara IG (1987): Down-regulation of protein kinase $\mathrm{C}$ and of an endogenous $80 \mathrm{k}$-Da substrate in transformed fibroblasts. J Biol Chem 262: $16546-16552$

Jpn J Human Genet 